\title{
Pasteurella testudinis sp. nov.: a Parasite of Desert Tortoises (Gopherus agassizi)
}

\author{
K. P. SNIPES AND E. L. BIBERSTEIN
}

Department of Veterinary Microbiology, University of California, Davis, California 95616

\begin{abstract}
A bacterium isolated from desert tortoises fits the major criteria for inclusion in the genus Pasteurella (gram-negative, nonmotile, pleomorphic rods that are facultatively anaerobic, fermentative in their attack on various carbohydrates, and catalase, nitratase, and oxidase positive). Tests performed for identifying this organism to the species level produced results that fit none of the currently accepted species of Pasteurella. This organism did not hydrolyze urea but did produce indole from tryptophane, hydrolyze $o$-nitrophenyl- $\beta$-D-galactopyranoside, and lyse sheep erythrocytes in agar. It fermented a variety of carbohydrates, producing acetic, lactic, propionic, and succinic acids as a result of glucose fermentation. All strains were highly susceptible to ampicillin $(\leq 0.5 \mu \mathrm{g} / \mathrm{ml})$, and most strains were susceptible to penicillin $(\leq 1 \mu \mathrm{g} / \mathrm{ml})$; the susceptibilities to tetracycline, streptomycin, and sulfonamides were variable. Serological tests revealed antigenic heterogeneity and suggested the presence of heat-extractable surface antigens in some strains. Mice succumbed to intranasal and intraperitoneal inoculations of large numbers of some of the strains. The guanine-plus-cytosine content of the deoxyribonucleic acid was between 46 and 47 mol\%. The Analytab Products API 20E bacterial identification system could not identify some strains of this organism. Other strains were identified as Pasteurella multocida or Aeromonas hydrophila at probability levels ranging from 1:69 to $1:>10^{6}$. Species status is proposed for these isolates under the name Pasteurella testudinis $\mathrm{sp}$. nov. The type strain of this species is strain UCD 90-23-79n (= ATCC 33688).
\end{abstract}

The genus Pasteurella currently is comprised of the following four species: Pasteurella multocida, Pasteurella haemolytica, Pasteurella ureae, and Pasteurella pneumotropica (27). To date, members of this genus have been isolated primarily from mammals and birds (4).

Within the last 15 years, reports of recovery of pasteurellae from poikilotherms have been increasing. Reichenbach-Klinke and Elkan (22) reported the isolation of $P$. haemolytica from cases of ulcerative stomatitis in reptile collections, and $P$. multocida was cultured from a pneumonic lung of an alligator that died after foreign body penetration of the stomach and resulting peritonitis (15). Pasteurella strains (species not given) have also been isolated from reptilian and amphibian abscesses $(12,16)$ and have been included on lists compiled by various investigators cataloging gram-negative bacteria associated with various infections (such as pneumonia and stomatitis) in reptiles $(13,31)$.

Recently, during the course of a bacteriological survey of the California desert tortoise (Gopherus agassizi), Snipes et al. isolated a bacterium that met the generic criteria of Pasteurella but did not correspond to any known species (29). This Pasteurella-like organism was cultured from captive tortoises displaying clinical signs of respiratory disease, from healthy captive tortoises, and from free-ranging tortoises from the Mojave Desert in southern California. The sources of the isolates from clinically ill tortoises included tracheal washes, pneumonic lung and stomatitic lesions, and oral and cloacal swabs. The bacterium was cultured from oral and cloacal swabs of healthy captive tortoises and from oral swabs and a tracheal wash of freeranging tortoises in the desert.

Among the major criteria for assigning a bacterium to the genus Pasteurella are the following characteristics: gram-negative, nonmotile, pleomorphic rods that are facultatively anaerobic, fermentative in their attack on various carbohydrates, and oxidase, nitratase, and usually catalase positive (27). The isolates recovered from tortoises possessed these characteristics.

Members of Pasteurella are identified to species mainly on the basis of their ability to catabolize urea, produce indole from tryptophane, lyse erythrocytes in agar, grow on MacConkey agar, and hydrolyze ortho-nitrophenyl$\beta$-D-galactopyranoside (ONPG).

The closely related genus Actinobacillus consists of nonmotile, gram-negative rods that reduce nitrates, hydrolyze ONPG and urea, grow on MacConkey agar, and do not produce indole 
TABLE 1. Basic biochemical characteristics of pasteurellae and actinobacilli

\begin{tabular}{|c|c|c|c|c|c|c|c|c|}
\hline \multirow[b]{2}{*}{ Organism } & \multicolumn{8}{|c|}{ Test results ${ }^{a}$} \\
\hline & Oxidase & $\begin{array}{l}\text { Nitrate } \\
\text { reduction }\end{array}$ & Urease & Indole & Motility & Hemolysis & ONPG & $\begin{array}{c}\text { Growth on } \\
\text { MacConkey agar }\end{array}$ \\
\hline P. multocida & + & + & - & + & - & - & - & - \\
\hline P. pneumotropica & + & + & + & + & - & - & d & - \\
\hline P. ureae & + & + & + & - & - & d & - & - \\
\hline P. haemolytica & + & + & - & - & - & + & d & + \\
\hline$P$. testudinis & + & + & - & + & - & + & d & $d$ \\
\hline Pasteurella sp. & + & + & - & - & - & - & d & - \\
\hline $\begin{array}{l}\text { Actinobacillus } \\
\text { sp. }\end{array}$ & d & + & + & - & - & d & + & + \\
\hline $\begin{array}{l}\text { Actinobacillus } \\
\text { equuli }\end{array}$ & d & + & + & - & - & - & + & + \\
\hline $\begin{array}{l}\text { Actinobacillus } \\
\text { suis }\end{array}$ & + & + & + & - & - & + & + & + \\
\hline $\begin{array}{c}\text { Actinobacillus } \\
\text { lignieresii }\end{array}$ & d & + & + & - & - & - & + & + \\
\hline
\end{tabular}

${ }^{a}+$, Positive; - , negative; $d$, different results have been observed.

(19). The tortoise isolates fail to meet two of these criteria, as they are urease negative and indole positive (Table 1). Therefore, we presumptively placed them in the genus Pasteurella and because of their hemolytic activity on blood agar, designated them indole-positive, hemolytic pasteurellae (IPHP). They were characterized further with regard to their physical, biochemical, and serological properties and with regard to their pathogenicity in mice.

\section{MATERIALS AND METHODS}

Bacterial strains. The designations and the origins of the strains used in this study are shown in Table 2.

TABLE 2. IPHP strains (P. testudinis) and their origins

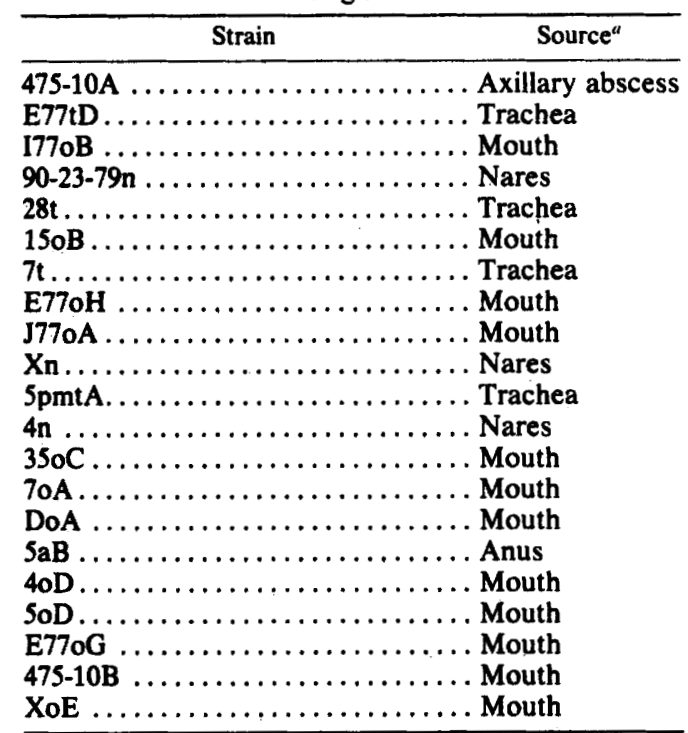

${ }^{a}$ All strains were isolated from desert tortoises $(G$. agassizi).
Biochemical characterization. Initially, all of the gram-negative isolates from tortoises were categorized by their reactions in triple sugar iron agar, Christensen urea agar, and sulfur indole motility medium, and by their cytochrome $c$ activity (oxidase test). Bacteria displaying the following characteristics were referred to as IPHP: triple sugar iron agar reaction, acid in slants and butts and no gas produced (7); no hydrolysis of urea in Christensen urea medium (7); no evidence of $\mathrm{H}_{2} \mathrm{~S}$ production in sulfur indole motility medium (7); nonmotile in sulfur indole motility or Gillies motility medium (7); indole positive in sulfur indole motility medium or tryptose broth (7); oxidase positive with the tetramethyl-p-phenylenediamine, dihydrochloride reagent (19); catalase positive (5); ONPG positive (6); colonies were mucoid, clear to white, hemolytic on $5 \%$ sheep blood agar but not in blood broth, and $1 \mathrm{~mm}$ in diameter after $48 \mathrm{~h}$; no growth on Simmons citrate (7); nitrate reduced to nitrites (7); and facultatively anaerobic as determined by the GasPak generator system (2).

Strains meeting these criteria were subjected to a battery of additional carbohydrate fermentation tests for further elucidation of their relationships to each other and to other related bacteria. The basal test medium $(10 \mathrm{~g}$ of peptone per liter, $4 \mathrm{~g}$ of beef extract per liter, $5 \mathrm{~g}$ of sodium chloride per liter, $0.016 \mathrm{~g}$ of bromcresol purple per liter) was adjusted to $\mathrm{pH} 7.6$ before it was autoclaved at $15 \mathrm{lb} / \mathrm{in}^{2}$ for $15 \mathrm{~min}$. Filtered-sterilized, $10 \%(\mathrm{wt} / \mathrm{vol})$ substrate solutions were added to give final concentrations of $1 \%$. Table 3 lists these tests and their results. All carbohydrate media were incubated at $37^{\circ} \mathrm{C}$ for 10 days before negative results were accepted as such.

API 20E test strips. Saline suspensions of the organisms were inoculated onto commercially prepared rapid bacterial identification strips (API 20E system; Analytab Products, Plainview, N.Y.). Each strip allowed the performance of 23 standard biochemical tests that are useful in the identification of the Enterobacteriaceae and other gram-negative bacteria (28). The directions of the manufacturer were followed for inoculation, reading, and interpretation of results.

Growth curves. The growth curves of broth cultures of two different IPHP strains were determined; $0.01 \mathrm{ml}$ of a saline bacterial emulsion standardized to an 
TABLE 3. Carbohydrate fermentation by IPHP (P. testudinis)

\begin{tabular}{|c|c|c|c|c|c|c|c|c|c|c|c|c|c|c|c|c|c|}
\hline \multirow[b]{2}{*}{ Strain } & \multicolumn{17}{|c|}{ Fermentation of: } \\
\hline & $\begin{array}{l}\text { Glu- } \\
\text { cose }\end{array}$ & Xylose & Sucrose & $\begin{array}{l}\text { Malt- } \\
\text { ose }\end{array}$ & $\begin{array}{c}\text { Galac- } \\
\text { tose }\end{array}$ & $\begin{array}{c}\text { Dex- } \\
\text { trin }\end{array}$ & Inositol & $\begin{array}{c}\text { Treha- } \\
\text { lose }\end{array}$ & $\begin{array}{c}\text { Arabi- } \\
\text { nose }\end{array}$ & $\begin{array}{c}\text { Sorbi- } \\
\text { tol }\end{array}$ & Starch & $\begin{array}{l}\text { Raffi- } \\
\text { nose }\end{array}$ & $\begin{array}{l}\text { Man- } \\
\text { nitol }\end{array}$ & Salicin & $\begin{array}{l}\text { Lac- } \\
\text { tose }\end{array}$ & Inulin & Glycerol \\
\hline $475-10 \mathrm{~A}$ & + & + & + & + & + & + & + & + & - & + & - & + & + & - & - & - & - \\
\hline E77tD & + & + & + & + & + & + & + & + & - & + & - & + & + & - & - & - & - \\
\hline $177 \mathrm{oB}$ & + & + & + & + & + & + & + & + & - & + & - & - & + & - & - & - & - \\
\hline $90-23-79 n$ & + & + & + & + & + & + & + & - & + & - & + & + & + & + & - & - & - \\
\hline $28 \mathrm{t}$ & + & + & + & + & + & + & - & + & - & - & - & + & - & + & - & - & - \\
\hline $150 B$ & + & + & + & + & + & - & - & - & - & + & - & + & - & - & - & - & - \\
\hline $7 \mathrm{t}$ & + & + & + & + & - & - & - & - & + & - & + & - & - & - & - & - & - \\
\hline E77oH & + & + & + & - & + & + & + & + & - & + & - & + & - & - & - & - & - \\
\hline J770A & + & + & + & - & - & + & + & - & - & + & + & - & + & - & - & - & - \\
\hline $\mathrm{Xn}$ & + & + & + & - & + & - & - & - & + & - & + & - & + & - & - & - & - \\
\hline SpmtA & + & + & + & - & - & - & - & + & - & - & - & - & + & - & - & - & - \\
\hline $4 n$ & + & + & + & + & + & - & + & - & + & - & + & + & + & + & - & - & - \\
\hline $350 \mathrm{C}$ & + & + & + & - & - & - & + & - & + & + & - & - & + & - & - & - & - \\
\hline $70 A$ & + & + & + & - & - & - & - & - & + & - & - & - & + & - & - & - & - \\
\hline DoA & + & + & + & + & + & + & - & + & - & - & + & - & - & - & + & - & - \\
\hline $5 \mathrm{aB}$ & + & + & + & + & + & + & - & + & - & - & + & - & - & - & + & - & - \\
\hline 40D & + & + & + & + & + & + & - & + & - & - & + & - & - & - & - & - & - \\
\hline $50 D$ & + & + & - & + & - & - & - & - & + & - & - & - & + & - & + & - & - \\
\hline E77oG & + & - & + & + & - & - & - & - & - & - & - & - & - & - & - & - & - \\
\hline
\end{tabular}


optical density of 0.5 at $540 \mathrm{~nm}$ was inoculated into brain heart infusion broth, and optical density readings were recorded until maximal growth was attained and the cultures were entering the stationary phase. At this time, plate counts were made by using the standard procedure of Miles et al. (17).

Antimicrobial agent susceptibility patterns. The susceptibilities of 13 strains to penicillin, ampicillin, tetracycline, streptomycin, and sulfonamides were determined by the method of Washington and Sutter (32).

Serology. Antiserum to one of the IPHP strains (strain 5 pmtA, which was isolated from the trachea of a dead tortoise) was prepared by immunizing a rabbit with a 24-h-old broth culture inactivated by adding Formalin to a final concentration of $0.5 \%$. The schedule used for immunization was that described by Edwards and Ewing for preparing antiserum against Klebsiella pneumoniae (8). The serological tests performed to compare the relatedness of biochemically similar strains of IPHP were divided into the following two groups: direct tube agglutination and indirect hemagglutination (IHA) tests.

(i) Direct tube agglutination. All tube agglutination trials were performed in test tubes ( 13 by $100 \mathrm{~mm}$ ); the serum was diluted up to $1: 5,000$.

The following antigen preparations were used in the direct agglutination tests: 24 -h-old brain heart infusion broth cultures inactivated by adding Formalin to a final concentration of $0.5 \%$; bacterial saline suspensions from 24- to 48-h-old sheep blood agar plate cultures adjusted to densities intermediate between the densities of McFarland nephelometer tubes 2 and 3; boiled brain heart infusion broth culture (heated at $100^{\circ} \mathrm{C}$ for $1 \mathrm{~h}$ ) cell residue suspensions adjusted to McFarland densities between 2 and 3; and autoclaved brain heart infusion broth culture (autoclaved at $120^{\circ} \mathrm{C}$ for $2 \mathrm{~h}$ ) cell residue suspensions with densities adjusted as described above.

All tube agglutination test mixtures were incubated in a $52^{\circ} \mathrm{C}$ water bath overnight. Standard controls were included.

Adsorbed antiserum was prepared by mixing packed, washed cells from 10 sheep blood agar plates with $1.5 \mathrm{ml}$ of antiserum and incubating the mixture for $1 \mathrm{~h}$ at $50^{\circ} \mathrm{C}$. The tube was then centrifuged for $20 \mathrm{~min}$ at $5,900 \times g$, and the serum was collected.

(ii) IHA tests. All IHA assays were performed with bovine erythrocytes. Basic antigen preparation was performed by following the method described by $\mathrm{Bi}$ berstein for the typing of $\boldsymbol{P}$. haemolytica (3). Supernatants from the boiled and autoclaved broth culture cell residues used in the direct tube agglutination assays were also used in an attempt to sensitize the bovine erythrocytes for IHA. IHA tests were performed in microtiter trays by previously described methods; two-fold dilutions of serum ranging from $1: 10$ to $1: 20,480$ were used (3). Standard controls were included.

The erythrocytes in the IHA tests were treated with the following preparations: untreated supernatant from a broth culture of strain 5pmtA; supernatant from a broth culture of strain $5 \mathrm{pmtA}$ that had been boiled at $100^{\circ} \mathrm{C}$ for $1 \mathrm{~h}$ before removal of cells by centrifugation; supernatant from a broth culture of strain 5pmtA that had been autoclaved at $120^{\circ} \mathrm{C}$ for $2 \mathrm{~h}$ before centrifugation of the cells; and supernatants from 13 other strains of IPHP that had been boiled at $100^{\circ} \mathrm{C}$ treated for $1 \mathrm{~h}$ before removal of cells by centrifugation. Test mixtures were incubated in a $37^{\circ} \mathrm{C}$ water bath with occasional shaking and were read after $60 \mathrm{~min}$. Hemagglutination was read simply as positive or negative, and the highest dilution that produced a positive result was recorded.

(iii) Attempted typing of IPHP from tortoises with $\boldsymbol{P}$. haemolytica typing sera. Erythrocytes treated with extracts of 14 strains of IPHP were exposed to antisera specific for $P$. haemolytica serotypes 1 through 12 . These IHA tests were performed and read by the method described by Biberstein for using the microtiter system, with the following exception: modified bovine erythrocytes were prepared by exposure to a supernatant from a broth culture that had been heated at $100^{\circ} \mathrm{C}$ for $60 \mathrm{~min}$ instead of $56^{\circ} \mathrm{C}$ for $30 \mathrm{~min} \mathrm{(3).} \mathrm{We}$ knew that heating at the higher temperature would facilitate reactivity of this particular bacterium, as judged by previous experiments.

Mouse pathogenicity. In a preliminary experiment to determine the pathogenicity of the IPHP for laboratory mice, 10 adult Swiss-Webster mice were inoculated intraperitoneally with $0.5-\mathrm{ml}$ portions of an overnight broth culture (approximately $2.7 \times 10^{9}$ cells of a strain isolated from the trachea of a dead tortoise per $\mathrm{ml}$ ). Controls (three each) were inoculated intraperitoneally with $0.5-\mathrm{ml}$ portions of Formalin-killed broth cultures. Necropsies were performed on mice that died, and cultures were taken from the heart, liver, lungs, peritoneum, and brain of each mouse.

Subsequently, four other adult C-57 mice were inoculated intranasally with $0.2-\mathrm{ml}$ portions of a broth culture containing approximately $4 \times 10^{7}$ bacteria per $\mathrm{ml}$. Necropsies were performed on mice that died, and heart, brain, lung, and liver cultures were taken. Two control mice received a Formalin-killed broth culture.

We attempted to determine the $50 \%$ lethal dose of this bacterium in laboratory mice. In our trial, a broth culture initially containing approximately $2 \times 10^{9}$ bacteria per $\mathrm{ml}$ was diluted in five-fold steps up to a dilution of $1: 3,125$, and $0.5-\mathrm{ml}$ portions of each dilution were inoculated intraperitoneally into five mice. The mice were observed for 4 days. Necropsies were performed on mice that died, and appropriate cultures were taken. Three control animals were also inoculated with undiluted Formalin-killed broth cultures.

DNA base composition. Chromosomal deoxyribonucleic acid (DNA) samples of two IPHP strains (strains 5pmta and 90-23-79n) were obtained and purified as described by Elwell et al. (9). The buoyant density of the DNA was determined, and the guanine-plus-cytosine $(\mathrm{G}+\mathrm{C})$ content was calculated from the buoyant density by the method of Schildkraut et al. (23).

Determination of fermentation products. The glucose fermentation products were identified by using an Anaerobic Bacteriology Analyzer gas chromatograph (Dohrman, Mountain View, Calif.). The conditions of analysis were as follows: thermal conductivity detector, $85 \mathrm{~mA}$; detector and column temperature, $130^{\circ} \mathrm{C}$; injection temperature, $145^{\circ} \mathrm{C}$ : stainless steel column $(182.9$ by $0.64 \mathrm{~cm})$ packed vith $100-$ to 120 -mesh Chromosorb W,AW (Johns-M ınville, Denver, Colo.); stationary phase, $10 \%$ SP $10,0-1 \%$ phosphoric acid (Supelco Co., Bellefonte, $\mathrm{Pa}$. helium flow rate, 120 $\mathrm{cm}^{3} / \mathrm{min}$. Ether and chlorofor extractions on 5-dayold peptone yeast extract glu se broth cultures were performed by the method of Holdeman and Moore 
TABLE 4. Fermentative reactions of IPHP (P. testudinis), $P$. haemolytica, and $P$. multocida from domestic animals $^{a}$

\begin{tabular}{|c|c|c|c|c|}
\hline \multirow[t]{2}{*}{ Substrate } & \multirow{2}{*}{$\begin{array}{l}\text { Results with IPHP } \\
\quad(n=10)\end{array}$} & \multirow{2}{*}{$\begin{array}{l}\text { Results with } \\
P . \text { multocida }\end{array}$} & \multicolumn{2}{|c|}{$\begin{array}{l}\text { Results with } \\
P . \text { haemolytica }\end{array}$} \\
\hline & & & Type A & Type T \\
\hline Glycerol & $-(0.0)^{b}$ & d & + & + \\
\hline Inositol & d (47.4) & - & d & $\mathrm{d}$ \\
\hline Mannitol & $\mathrm{d}(58.0)$ & + & + & + \\
\hline Sorbitol & d (36.9) & d & + & + \\
\hline Arabinose & d (42.1) & d & + & - \\
\hline Galactose & d (63.2) & + & + & d \\
\hline Glucose & $+(100.0)$ & + & + & + \\
\hline Lactose & d (15.8) & $d$ & d & - \\
\hline Xylose & $+(94.7)$ & d & + & - \\
\hline Maltose & $\mathrm{d}(68.4)$ & d & + & + \\
\hline Sucrose & $+(94.7)$ & + & + & + \\
\hline Trehalose & $\mathrm{d}(42.1)$ & d & - & + \\
\hline Raffinose & d (36.9) & d & + & d \\
\hline Dextrin & $d(52.6)$ & d & + & - \\
\hline Inulin & $-(0.0)$ & - & d & - \\
\hline Starch & d (36.9) & - & d & - \\
\hline Salicin & d (15.8) & - & - & + \\
\hline \multicolumn{5}{|l|}{$\begin{array}{l}\text { Acid fermentation } \\
\text { products }\end{array}$} \\
\hline Acetic acid & + & + & + & $N^{c}$ \\
\hline Lactic acid & + & + & + & ND \\
\hline Propionic acid & + & + & + & ND \\
\hline Succinic acid & + & + & + & ND \\
\hline
\end{tabular}

${ }^{a}$ Data from references $11,26,27$, and 30 .

${ }^{b} \mathrm{~d}$, Different types;,$+ \geq 90 \%$ positive;,$- \geq 90 \%$ negative. The values in parentheses indicate the percent positive.

ND, Not done.

(14). The Peptone yeast extract glucose broth used contained (per $100 \mathrm{ml}) 1.0 \mathrm{~g}$ of peptone, $1.0 \mathrm{~g}$ of yeast extract, $0.4 \mathrm{ml}$ of resazurin, $4.0 \mathrm{ml}$ of salts solution, 1.0 $\mathrm{ml}$ of a vitamin $\mathrm{K}$-heme solution, $0.05 \mathrm{~g}$ of cysteine hydrochloride (hydrated), and $1 \mathrm{~g}$ of glucose.

\section{RESULTS}

Biochemical characterization. Table 3 shows the results of carbohydrate fermentation tests performed with 19 IPHP isolates and 17 substrates. All of these strains fulfilled the criteria for the genus Pasteurella in that they were nonmotile, oxidase-positive, fermenting, facultative anaerobes. All were hemolytic on sheep blood agar, reduced nitrates to nitrites, evolved indole from tryptose broth, and produced acidity from glucose. They uniformly failed to grow on Simmons citrate agar and to produce acid from glycerol and inulin. The majority showed $\beta$ galactosidase activity (15 of 19 isolates) and grew on MacConkey agar (12 of 19). There was little uniformity with regard to carbohydrate fermentation among the strains; only two strains (strains DoA and $5 \mathrm{aB}$ ) had identical patterns.

Table 4 shows the IPHP fermentation behav- ior along with the expected reactions of $P$. multocida and two biovars of $P$. haemolytica. These data suggest no clear relationship to either one of these species. It may be worthwhile to point out that, as with $P$. haemolytica, fermentation of both trehalose and arabinose never occurred in the same strain (Table 1).

API 20E test strips. Table 5 shows the results of attempts to use the API 20E system for identifying the IPHP strains.

There was reasonable uniformity in the results of tests that were not based on carbohydrate fermentation, but variation occurred between strains with regard to fermentation of many of the carbohydrates. Glucose, mannitol, and sucrose were the only three sugars which were attacked uniformly with resulting acid production. There were also discrepancies between the results obtained with the API 20E test system and those obtained with conventional biochemical tests. For example, isolate 40D was ONPG positive when it was tested in the conventional manner but negative in the API strip test. Isolate $70 \mathrm{~A}$ produced indole in tryptose broth but not in the API strip test.

The Analytab Products computer service provided Pasteurella as the most frequently encountered diagnosis of the IPHP strains. $P$. 


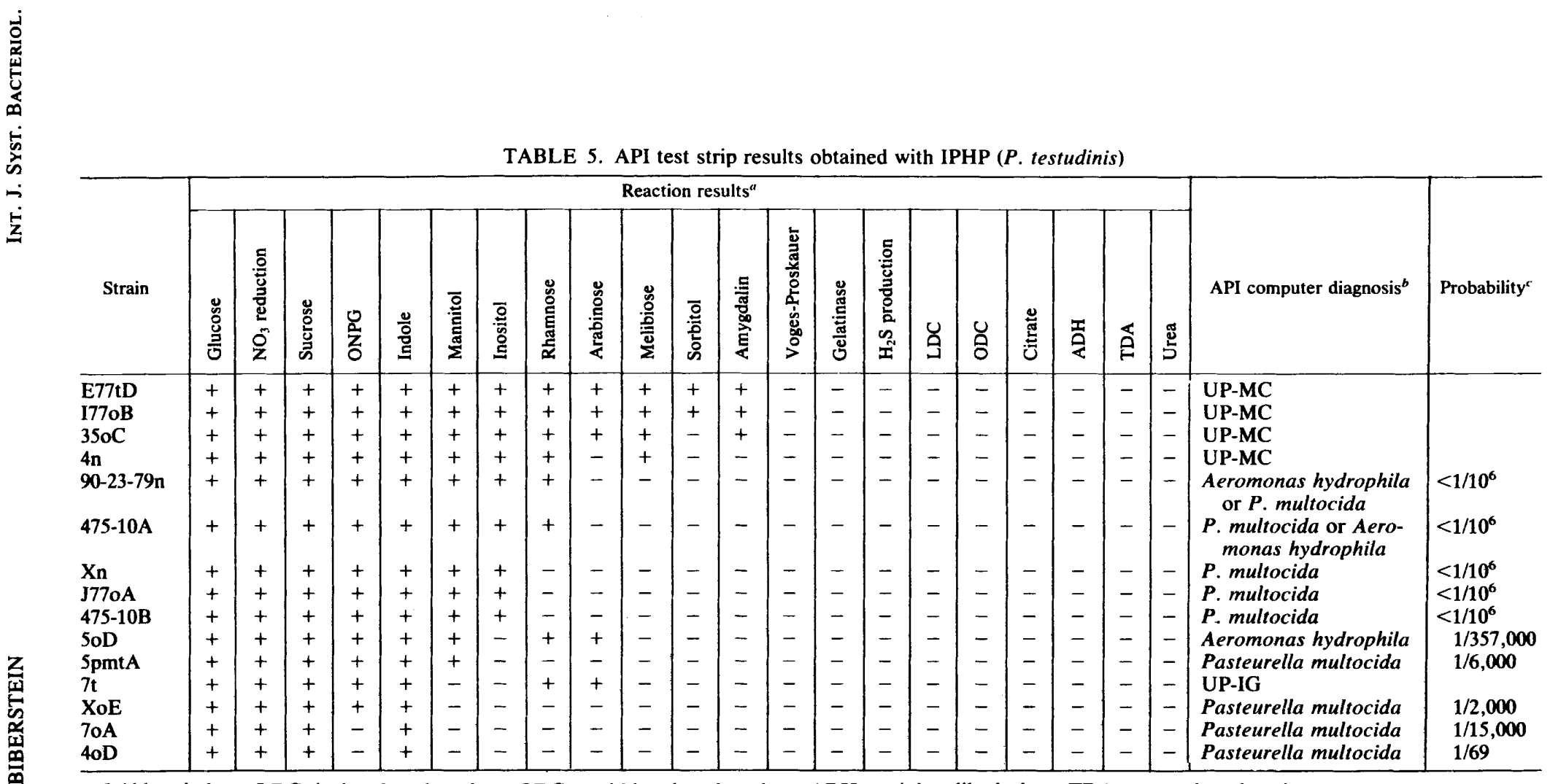

${ }^{a}$ Abbreviations: LDC, lysine decarboxylase; ODC, ornithine decarboxylase; ADH, arginine dihydrolase; TDA, tryptophan deaminase.

b UP-MC, Unacceptable profile, probably mixed culture; UP-IG, unacceptable profile, insufficient growth.

$c<1 / 10^{6}$, Unacceptable profile; $1 / 357,000$, very doubtful; $1 / 15,000$, good likelihood; $1 / 6,000$, acceptable identification; $1 / 2,000$, very good identification; $1 / 69$, excellent identification. 
TABLE 6. Minimal concentrations of antimicrobial agents inhibitory to IPHP ( $P$. testudinis)

\begin{tabular}{lccccc}
\hline \multirow{2}{*}{ Strain } & \multicolumn{5}{c}{ Minimal inhibitory concn $(\mu \mathrm{g} / \mathrm{ml})$ of: } \\
\cline { 2 - 7 } & $\begin{array}{c}\text { Penicil- } \\
\text { lin }\end{array}$ & $\begin{array}{c}\text { Ampicil- } \\
\text { lin }\end{array}$ & $\begin{array}{c}\text { Tetracy- } \\
\text { cline }\end{array}$ & $\begin{array}{c}\text { Strepto- } \\
\text { mycin }\end{array}$ & $\begin{array}{c}\text { Sulfon- } \\
\text { amide }\end{array}$ \\
\hline I77oB & $<0.25$ & 0.25 & 8 & 0.5 & 0.5 \\
XoE & $<0.25$ & $<0.125$ & 8 & 0.25 & $<0.25$ \\
E77tD & $<0.25$ & 0.25 & 16 & 1 & 2 \\
4oD & $<0.25$ & 0.125 & 16 & 0.5 & $<0.25$ \\
475-10A & $<0.25$ & 0.125 & 8 & 0.5 & 4 \\
5oD & $<0.25$ & 0.125 & 16 & 0.5 & $<0.25$ \\
5pmtA & $<0.25$ & 0.125 & 16 & 0.5 & 0.25 \\
35oC & $<0.25$ & 0.5 & 8 & 0.5 & 0.5 \\
J77oA & $<0.25$ & 0.25 & 8 & 0.5 & $<0.25$ \\
7oA & 0.5 & 0.125 & 2 & 16 & 4 \\
Xn & 0.5 & 0.125 & 2 & 8 & 4 \\
90-23-79n & 1 & 0.125 & 2 & 8 & 4 \\
4n & 1 & 0.25 & 1 & 8 & 0.5 \\
\hline
\end{tabular}

multocida was listed as a possible species for nine of the strains tested. Four of these were reported to be $\boldsymbol{P}$. multocida, with "acceptable" probabilities ranging from $1 / 15,000$ to $1 / 69$. A few possibilities of Aeromonas were listed, but all had very low probabilities.

Growth curves. IPHP had a lag phase of approximately $7 \mathrm{~h}$ and a logarithmic growth phase of approximately $4 \mathrm{~h}$. Therefore, on the average, about $11 \mathrm{~h}$ was required to attain the stationary phase.

Antimicrobial agent susceptibility patterns. Table 6 shows the results of antibiotic susceptibility assays for 13 isolates of IPHP. These isolates were susceptible to ampicillin and penicillin (most minimal inhibitory concentrations, $\leq 0.250$ $\mu \mathrm{g} / \mathrm{ml}$ ); similar values were obtained for all of the isolates. The majority of the isolates tested were fairly resistant to tetracycline (minimal inhibitory concentration, 8 to $16 \mu \mathrm{g} / \mathrm{ml}$ ), and 7 of 13 isolates were moderately susceptible to streptomycin $(50 \mu \mathrm{g} / \mathrm{ml})$. The results with the sulfonamides were variable.

Serology. (i) Direct tube agglutination. Table 7 shows the overall results of the agglutination tests for the 13 strains tested.

The agglutination tests involving antiserum prepared against one strain of IPHP (strain 5pmtA) and antigens derived from 13 other IPHP isolates revealed four isolates which agglutinated with a titer of 1:50 or more. The homologous titer was 1:500. Seven of the 13 strains did not react at all, and all controls were negative.

When the cross-agglutination test was repeated with antigens that had been boiled at $100^{\circ} \mathrm{C}$, six strains reacted with a titer of 1:500 or more. The homologous titer with the boiled antigen was $1: 1,000$. In this experiment, only one isolate failed to react with serum against strain $5 \mathrm{pmtA}$.
TABLE 7. Direct agglutination studies (complete agglutination) involving strains of IPHP ( $P$. testudinis)

\begin{tabular}{llll}
\hline \multicolumn{1}{c}{ Strain } & $\begin{array}{c}\text { Titer vs } \\
\text { anti- } \\
\text { 5pmtA } \\
\text { serum }\end{array}$ & $\begin{array}{c}\text { Titer vs } \\
\text { anti-5pmtA } \\
\text { serum after } \\
\text { antigens were } \\
\text { boiled for } 1 \mathrm{~h}\end{array}$ & $\begin{array}{c}\text { Titer vs anti- } \\
\text { 5pmt A serum } \\
\text { after adsorption } \\
\text { with 90-23-79n }\end{array}$ \\
\hline 90-23-79n & $1: 100$ & $1: 500$ & 0 \\
Xn & 0 & $1: 10$ & ND $^{a}$ \\
4n & 0 & 0 & ND \\
4oD & 0 & $1: 10$ & ND \\
J77oA & $1: 50$ & $1: 1,000$ & 0 \\
7oA & $1: 100$ & $1: 1,000$ & 0 \\
5oD & $1: 50$ & $1: 1,000$ & $1: 10$ \\
I77oB & 0 & $1: 20$ & ND \\
E77tD & 0 & $1: 20$ & ND \\
35oC & $1: 10$ & $1: 1,000$ & ND \\
XoE & 0 & $1: 10$ & ND \\
475-10B & $1: 20$ & $1: 1,000$ & ND \\
475-10A & 0 & $1: 20$ & ND \\
5pmtA & $1: 500$ & $1: 1,000$ & 0 \\
\hline
\end{tabular}

${ }^{a} \mathrm{ND}$, Not done.

The titers of the previously reactive strains increased (Table 7). All controls were negative. When the homologous titer was checked with autoclaved antigen $\left(120^{\circ} \mathrm{C}\right.$ for $\left.2 \mathrm{~h}\right)$ derived from the homologous strain, a titer of 1:500 was observed. In light of similar titers obtained after boiling and autoclaving of the homologous antigen, further tests on heterologous antigens were performed after boiling only.

The four heterologous antigens which the antiserum agglutinated at a titer of 1:50 without boiling and the homologous strain antigen were tested further to examine the extent of antigenic similarity among these five isolates. After adsorption of the antiserum with one of the heterologous strains (strain 90-23-79n), the heterologous cross-reacting strains and the homologous strain failed to react with the adsorbed antiserum (Table 7).

(ii) IHA. The IPHP isolates were generally unreactive in the IHA tests. Erythrocytes treated with an unheated bacterial culture did not react with the homologous antiserum. When a culture was boiled for $1 \mathrm{~h}$ before being used for sensitizing erythrocytes, and IHA titer of 1:80 was obtained. The only strain other than strain $5 \mathrm{pmtA}$ capable of sensitizing erythrocytes for IHA by strain $5 \mathrm{pmtA}$ serum was strain $50 \mathrm{D}$, which had been isolated antemortem from the oral cavity of the same tortoise as strain 5pmtA.

Autoclaving the cultures before attempts to sensitize erythrocytes failed to produce active preparations.

All controls were negative.

(iii) $\boldsymbol{P}$. haemolytica typing sera. When erythrocytes treated with boiled IPHP cultures were 
TABLE 8. Determination of the $50 \%$ lethal dose of strain 5pmtA inoculated intraperitoneally

\begin{tabular}{|c|c|c|}
\hline Dilution $^{a}$ & $\begin{array}{l}\text { No. of dead } \\
\text { mice/no. } \\
\text { inoculated }\end{array}$ & Culture results \\
\hline$\overline{\text { Undiluted }}$ & $4 / 5$ & $\begin{array}{l}\text { Heart culture positive } \\
\text { for all mice, moder- } \\
\text { ate numbers }\end{array}$ \\
\hline $1: 5$ & $0 / 5$ & $\begin{array}{l}\text { All mice appeared to be } \\
\text { clinically ill } \leq 2 \text { days } \\
\text { post-inoculation }\end{array}$ \\
\hline $1: 25$ & $0 / 5$ & $\begin{array}{l}\text { Two mice appeared to } \\
\text { be clinically ill }\end{array}$ \\
\hline $1: 125$ & $0 / 5$ & \\
\hline $1: 625$ & $0 / 5$ & \\
\hline $1: 3,125$ & $0 / 5$ & \\
\hline Control & $0 / 3$ & \\
\hline
\end{tabular}

a The original culture contained $2 \times 10^{9}$ bacteria per $\mathrm{ml}$.

${ }^{b}$ Number of dead mice within 4 days.

exposed to $P$. haemolytica typing sera, no reactions were observed.

Mouse pathogenicity. The results of the mouse inoculation studies were as follows: all 10 mice inoculated intraperitoneally with strain $5 \mathrm{pmtA}$ died, whereas 3 of 4 mice inoculated intranasally with strain 5pmtA died. Moderate to high numbers of strain 5pmtA were recovered from the livers and lungs of all mice inoculated intraperitoneally, whereas brain cultures from animals that died from intranasal inoculation yielded IPHP in low numbers. Smears of brains from mice that were inoculated intraperitoneally contained rods which appeared to have capsules when they were stained with Wright stain. Liver and heart cultures from the three mice which died after intranasal inoculation produced IPHP in moderate numbers. No mouse inoculated with a Formalinized culture died in any of the tests. Mice similarly inoculated with another strain (strain 90-23-79n) suffered only temporary illness.

An attempt to determine the $50 \%$ lethal dose of strain 5pmtA when it was inoculated intraperitoneally gave the results shown in Table 8 . The 50\% lethal dose for IPHP was approximately $3.5 \times 10^{8}$ bacteria inoculated intraperitoneally, as determined by the method of Reed and Muench (21).

DNA base compositions. The $\mathrm{G}+\mathrm{C}$ contents of the DNAs of the two strains examined (strains 5pmtA and 90-23-79n) were $46.90 \pm 0.20$ and $46.54 \pm 0.06 \mathrm{~mol} \%$, respectively. These values were based on three determinations for each strain.

Fermentation products. The fermentation end products detected by gas chromatographic analyses of the glucose broth cultures were acetic, propionic, lactic, and succinic acids.

\section{DISCUSSION}

Nonenteric, nonmotile, fermentative, gramnegative rods are candidates for membership mainly in three genera (viz., Haemophilus, Pasteurella, and Actinobacillus). The qualifications for membership in the genus Haemophilus are certain growth factor requirements, which the organisms which we studied lack. The genus Actinobacillus was ruled out by the criteria of urease activity and absence of indole production (Table 1). Therefore, it is evident that the genus Pasteurella best suits the bacterium studied. The range of $\mathrm{G}+\mathrm{C}$ values reported for Pasteurella species by Flossmann et al. (10) includes the values determined for two strains of IPHP, and the products of fermentation in the isolates which we studied are identical to those of known strains of $P$. haemolytica and $P$. multocida (Table 4).

A comparison of the IPHP with the existing species of Pasteurella revealed the following striking similarities with $\boldsymbol{P}$. haemolytica (Tables 1 and 4): hemolytic activity on blood agar, $\beta$ galactosidase activity in some biovars, ability of most strains (78.9\%) to grow on MacConkey agar, and some common fermentation patterns. Most reminiscent of $P$. haemolytica pertaining to the latter is the apparent mutual exclusiveness of arabinose fermentation and trehalose fermentation, which, in true members of $P$. haemolytica, forms the basis for recognition of biovars A and T. With biovar A of $P$. haemolytica, however, arabinose fermentation usually is associated with xylose fermentation and rules out salicin fermentation. In contrast, type T strains typically do not acidify xylose but do ferment salicin in addition to trehalose. No such correlations appear to apply to IPHP.

The most significant difference between $P$. haemolytica and the IPHP is the consistent production of indole by the latter, an activity that has been observed only once in a confirmed strain of $P$. haemolytica (1). Mraz (18) has described an indole-forming variant of $P$. haemolytica of bovine origin which differs, howev$\mathrm{er}$, in a number of aspects from the tortoise isolates. In several fermentation tests, particularly those involving sucrose, mannitol, inositol, trehalose, lactose, and especially glycerol, the bulk of the strains described by Mraz exhibited activity which contrasted with that of IPHP. Furthermore, unlike our results, the results of Mraz showed serological relationships between established $P$. haemolytica strains and his indole-positive cultures, and his $\mathrm{G}+\mathrm{C}$ values (average, $40.3 \mathrm{~mol} \%$ ) were much closer to the $\mathrm{G}+\mathrm{C}$ value of $P$. haemolytica $(40.7 \mathrm{~mol} \%)$ than the $\mathrm{G}+\mathrm{C}$ values obtained from tortoise isolates (average, $\mathbf{4 6 . 7 2} \mathrm{mol} \%$ ). Finally, his cultures apparently had no effect on mice, whereas some of our 
strains caused fatal infections when they were given in high numbers and observable illness when they were given in lower concentrations. All of these differences and the origins of the strains rule out any possible identity of the two groups of indole-positive hemolytic organisms.

Apart from indole production, the following characteristics separate IPHP from $P$. haemolytica: inconsistency with regard to growth on MacConkey agar, uniform inability to ferment glycerol and usually mannitol; and untypability in $\boldsymbol{P}$. haemolytica typing serum. Our organism differs from $P$. multocida and $P$. pneumotropica in that it is hemolytic and includes a large majority of strains which are capable of growing on MacConkey agar. The last criterion also separates IPHP from $P$. ureae, as does indole production. The $\mathrm{G}+\mathrm{C}$ value of IPHP, although somewhat high, is within the range of values for existing species of Pasteurella (10) and rules out membership of IPHP in the genus Aeromonas (24).

Therefore the organism described here as IPHP represents a new kind of Pasteurella, for which we propose species status under the name Pasteurella testudinis sp.nov. (tes.tú.di.nis. L. noun testudo tortoise; L. gen. noun testudinis of the tortoise).

Description of Pasteurella testudinis sp. nov.

Cell characteristics: gram-negative, nonmotile, nonsporeforming, pleomorphic rods, 0.2 by 1.5 to $2.0 \mu \mathrm{m}$; the majority of the strains appear to possess capsule-like surface layers.

Surface colonies on sheep blood agar are white, mucoid, and approximately 0.5 to $1.0 \mathrm{~mm}$ in diameter after 24 to $48 \mathrm{~h}$ of incubation at 37 or $20^{\circ} \mathrm{C}$; colonies on sheep blood agar regularly produce a beta-hemolytic zone.

Atmospheric requirements: facultatively anaerobic; extra $\mathrm{CO}_{2}$ not required for growth in air.

Biochemical reactivity: chemoorganotrophic; the various carbohydrates fermented are listed in Tables 3 and 5.

Fermentation end products from glucose: acetic, propionic, lactic, and succinic acids are produced; gas is not produced.

$\mathrm{G}+\mathrm{C}$ content of DNA: $46.7 \pm 0.2 \mathrm{~mol} \%(\mathrm{CsCl}$ gradient separation).

Serology: possibility of serovars, as evidenced by the close serological relatedness of 5 of 13 strains in direct tube agglutination tests. The similarity among these five strains appears to be a result of related somatic antigens. Heatextractable surface antigens are suggested by agglutination and IHA reactions.

Sources: so far, isolated from pneumonic lesions, abscesses, and gastrointestinal tracts of California desert tortoises.

Pathogenicity: associated with multifocal bronchopneumonia in California desert tortoises. The disease is not highly contagious under experimental conditions, and the bacterium appears to be commensal in healthy free-ranging tortoises. Some strains are pathogenic for mice when inoculated intraperitoneally or intranasally.

Type strain: $90-23-79 n$ (= ATCC 33688). The description of the type strain is the same as that for the species.

\section{ACKNOWLEDGMENTS}

We thank Joanne Tredick, University of California, Davis, and $\mathrm{H}$. Bercovier, Institut Pasteur, Paris, France, for assistance in the determination of the $\mathrm{G}+\mathrm{C}$ values.

\section{REPRINT REQUESTS}

Address reprint requests to: K. P. Snipes, Department of Veterinary Microbiology, University of California, Davis, CA 95616.

\section{LITERATURE CITED}

1. Aarslefi, B., E. L. Biberstein, B. J. Shreeve, and D. A. Thompson. 1970. A study of untypable strains of Pasteurella haemolytica. J. Comp. Pathol. 80:493-498.

2. Allen, S. D., and J. A. Siders. 1980. Procedures for isolation and characterization of anaerobic bacteria, p. 397417. In E. H. Lennette, A. Balows, W. J. Hausler, Jr., and J. P. Truant (ed.), Manual of clinical microbiology, 3rd ed. American Society for Microbiology, Washington, D.C.

3. Biberstein, E. L. 1978. Biotyping and serotyping of Pasteurella haemolytica, p. 253-269. In T. Bergan (ed.), Methods in microbiology, vol. 10. Academic Press, Inc., New York.

4. Biberstein, E. L. 1978. The pasteurelloses, p. 495-514. In J. Steele (ed.), Handbook of zoonoses. CRC Press, Boca Raton, Fla.

5. Carter, G. R. 1979. Diagnostic procedures in veterinary bacteriology and mycology, 3rd ed. Charles C Thomas, Publisher, Springfield, Ill.

6. Cowan, S. T., and K. J. Steel. 1965. Manual for the identification of medical bacteria. Cambridge University Press, Cambridge.

7. Difco Laboratories. 1969. Difco manual of dehydrated culture media and reagents for microbiological and clinical laboratory procedures, 9th ed. Difco Laboratories, Detroit, Mich.

8. Edwards, P. R., and W. H. Ewing. 1972. Identification of the Enterobacteriaceae, 2nd ed. Burgess Publishing Co., Minneapolis, Minn.

9. Elwell, L. P., J. DeGroaf, D. Seibert, and S. Falkow. 1975. Plasmid-linked ampicillin resistance in Haemophilus influenzae type b. Infect. Immun. 12:404-410.

10. Flossmann, K. O., B. Pohrmann, H. Feist, and W. Erler. 1979. Desoxyribonukleinsäuren aus Pasteurella multocida und Pasteurella haemolytica. Arch. Exp. Vet. Med. 33:393-402.

11. Frederiksen, W. 1973. Pasteurella taxonomy and nomenclature. Contrib. Microbiol. Immunol. 2:170-176.

12. Frye, F. L. 1977. Bacterial and fungal diseases of captive reptiles, p. 787-791. In R. W. Kirk (ed.), Current veterinary therapy, vol. 6. The W. B. Saunders Co., Philadelphia.

13. Henriksen, P., and D. L. Graham. 1972. Diagnosis and treatment of disease in the turtle. Iowa State Univ. Vet. 34:29-32.

14. Holdeman, L. V., and W. E. C. Moore (ed.). 1975. Anaerobe laboratory manual, 3rd ed. Virginia Polytechnic Institute and State University Anaerobe Laboratory, Blacksburg. 
15. Mainster, M. E., F. T. Lynd, P. C. Cragg, and J. Karger. 1973. Treatment of multiple cases of $P$. multocida and staphylococcal pneumonia in Alligator mississippiensis on a herd basis, p. 34-36. In Annual Proceedings of the American Association of Zoo Veterinarians. AAZV, Houston.

16. Mayer, H., and W. Frank. 1974. Bacteriological studies on reptiles and amphibians. Zentralbl. Bakteriol. Parasitenkd. Infektionskr. Hyg. Abt. 1 Orig. Reihe 229:470-481.

17. Miles, A. A., S. S. Misra, and J. O. Irwin. 1938. The estimation of the bactericidal power of the blood. J. Hyg. 38:732-749.

18. Mraz, D. 1970. Indolbildende Variante des Actinobacillus haemolyticus. Zentralbl. Bakteriol. Parasitenkd. Infektionskr. 213:93-102.

19. Paik, G. 1980. Reagents, stains, and miscellaneous test procedures, p. 1000-1024. In E. H. Lennette, A. Balows, W. J. Hausler, Jr., and J. P. Truant (ed.), Manual of clinical microbiology, 3rd ed. American Society for Microbiology, Washington, D.C.

20. Phillips, J. E. 1974. Actinobacillus, p. 373-377. In R. E. Buchanan and N. E. Gibbons (ed.), Bergey's manual of determinative bacteriology, 8 th ed. The Williams \& Wilkins Co., Baltimore.

21. Reed, L. J., and H. Muench. 1938. A simple method for estimating fifty percent endpoints. Am. J. Hyg. 27:493497.

22. Reichenbach-Klinke, H., and E. Elkan. 1966. The principal diseases of lower vertebrates. Academic Press, Inc., New York.

23. Schildkraut, C. L., J. Marmur, and P. Doty. 1962. Determination of the base composition of deoxyribonucleic acid from its buoyant density in CsCl. J. Mol. Biol. 4:430-433.
24. Schubert, R. H. W. 1974. Aeromonas, p. 345-348. In R. E. Buchanan and N. E. Gibbons (ed.), Bergey's manual of determinative bacteriology, 8th ed. The Williams \& Wilkins Co., Baltimore.

25. Shreeve, B. J., and D. A. Thompson. 1970. Studies on the carriage of Pasteurella hemolytica in lambs. J. Comp. Pathol. 80:107-112.

26. Smith, G. R. 1961. The characteristics of two types of Pasteurella haemolytica associated with different pathological conditions in sheep. J. Pathol. Bacteriol. 81:431440.

27. Smith, J. E. 1974. Pasteurella, p. 370-373. In R. E. Buchanan and N. E. Gibbons (ed.), Bergey's manual of determinative bacteriology, 8 th ed. The Williams \& Wilkins Co., Baltimore.

28. Smith, P. B., K. M. Tomfohrde, D. L. Rhoden, and A. Balows. 1972. API system: a multitube method for identification of Enterobacteriaceae. Appl. Microbiol. 24:449452.

29. Snipes, K. P., E. L. Biberstein, and M. E. Fowler. 1980. A Pasteurella sp. associated with respiratory disease in captive desert tortoises. J. Am. Vet. Med. Assoc. 177:804-807.

30. Stamp, J. T., A. A. Watt, and J. R. Thomlinson. 1955. Pasteurella hemolytica septicaemia of lambs. J. Comp. Pathol. Ther. 65:183-196.

31. Wallach, J. D. 1969. Medical care of reptiles. J. Am. Vet. Med. Assoc. 155:1017-1034.

32. Washington, J. A., II, and V. L. Sutter. 1980. Dilution susceptibility test: agar and macro-broth dilution procedures, p. 453-458. In E. H. Lennette, A. Balows, W. J. Hausler, Jr., and J. P. Truant (ed.), Manual of clinical microbiology, 3rd ed. American Society for Microbiology, Washington, D.C. 